\title{
DEKRIMINALISASI PENGGUNA NARKOBA: POLITIK KRIMINAL PENANGGULANGAN PROBLEMATIKA OVERCAPACITY LEMBAGA PERMASYARAKATAN DI INDONESIA
}

\author{
Indah Maryani \\ Universitas Negeri Semarang \\ Email: indahmaryani991@ students.unnes.ac.id
}

\begin{abstract}
Prison overcapacity is one of the crucial legal issues at this time, in this case the overcapacity has reached 204\%. The large number of narcotic convicts is one of the causes of prison overcapacity, related to this, narcotics convicts reach 50\% of the total inmates in Indonesia. The purpose of this study was to determine the need for drug users, namely abusers and drug addicts to be handled with non-penal efforts and decriminalization of drug abusers in order to reduce the level of overcapacity of prisons in Indonesia. The research method used is normative legal research that prioritizes secondary data. The results of the study confirm that addicts and abusers are victims who are entitled to protection so as not to become victims of criminal acts and have the right to obtain guarantees or rehabilitation for the losses they have received. So that non-penal efforts are needed to protect the rights of victims and decriminalization needs to be done as part of criminal politics to bring criminal law to a better direction, in this case upholding the rights of victims and being a solution to the problem of overcapacity in prisons in Indonesia.
\end{abstract}

\section{Keywords: Overcapacity, decriminalization, rehabilitation}

\section{PENDAHULUAN}

Dekriminalisasi sebagai suatu bagian dari pembaharuan hukum pidana, dalam hal inu kejahatan narkotika yang khususnya terkait penyalahguna dan pecandu narkotika. Adapun pembaharuan hukum pidana atau politik criminal ini bertujuan untuk menciptakan hukum atau memperbaiki hukum menjadi hukum yang lebih baik. Dekriminalisasi merupakan suatu tindakan yang awalnya dikenal sebagai tindak pidana mengalami perubahan menjadi tindakan yang digolongkan bukan lagi sebagai tindak pidana ${ }^{1}$. Dekriminalisasi pecandu dan penyalahguna narkotika diperlukan mengingat bahwa mereka sebagai subjek hukum yang melakukan kesalahan karena menjadi korban dari tindak

\footnotetext{
1 Purnamasari, Andi Intan.2019. Dekriminalisasi Tindak Pidana: Membedah Keadilan Bagi Terpidana Dan Mantan Terpidana.Vol.2 No.1, hlm. 13-23.
} 


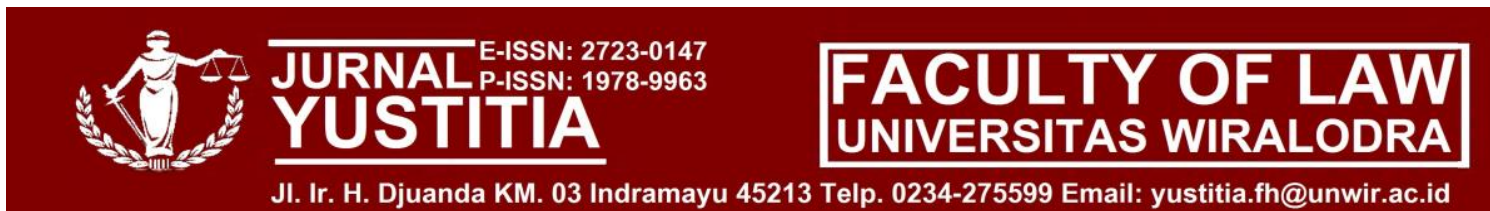

pidana pengedar narkoba, maka selayaknya keduanya diprioritaskan menjalani rehabilitasi bukan menjalani perampasan kemerdekaan dalam penjara.

Terpidana yang karena perbuatannya telah dijatuhi putusan inkracht dan ditahan tetaplah manusia yang seharusnya dimanusiakan. Overkapasitas lapas membuat pelaksanaan pidana penjara sebagai upaya pembinaan terpidana dalam lapas menjadi tidak berjalan efektif, dalam hal ini satu ruang dihuni 20-30 orang. Data dari Koalisi Pemantau Peradilan pada bulan Maret 2020 bahwa overkapasitas mencapai 204\% dengan narapidama 270.466 orang sedangkan total kapasitas lapas di indoneisa adalah 132.335 orang $^{2}$. Disisi lain data dari Direktorat Jenderal Pemasyarakatan per tanggal 09 September 2021, bahwa jumlah narapidana dan tahanan di Indonesia mencapai 266.663 dengan kapasitas hanya 132.107 orang sehingga over kapasitas mencapai $201 \%$. Kemudian lapas dalam praktiknya didominasi oleh tindak pidana narkotika, bahwa jumlah tahanan dan narapidana narkotika mencapai $50 \%$ atau lebih tepatnya 136.030 orang dari total tahanan dan narapidana yang ada $^{3}$ Tidak jauh berbeda dari data Badan Narkotika Nasional bahwa terdapat 129.820 narapidana narkotika dengan 77.849 orang merupakan bandar dan 51.971 merupakan pecandu ${ }^{4}$.

Berikut data kepadatan lapas/rutan di Jawa Tengah: ${ }^{5}$

\begin{tabular}{|c|c|c|c|}
\hline LAPAS/RUTAN & $\begin{array}{l}\text { JUMLAH } \\
\text { PENGHUNI }\end{array}$ & KAPASITAS & $\begin{array}{l}\text { \% MELEBIHI } \\
\text { KAPASITAS }\end{array}$ \\
\hline $\begin{array}{l}\text { LAPAS KELAS I BATU HIGH RISK } \\
\text { NARKOTIKA NUSAKAMBANGAN }\end{array}$ & 58 & 96 & 0 \\
\hline LAPAS KELAS I SEMARANG & 1758 & 663 & 165 \\
\hline LAPAS KELAS II A AMBARAWA & 490 & 222 & 121 \\
\hline $\begin{array}{l}\text { LAPAS KELAS II A BESI } \\
\text { NUSAKAMBANGAN }\end{array}$ & 430 & 365 & 18 \\
\hline $\begin{array}{l}\text { LAPAS KELAS II A KEMBANG KUNING } \\
\text { NUSAKAMBANGAN }\end{array}$ & 472 & 275 & 72 \\
\hline LAPAS KELAS II A KENDAL & 302 & 126 & 140 \\
\hline LAPAS KELAS II A MAGELANG & 557 & 221 & 152 \\
\hline
\end{tabular}

2 Asprilla Dwi Adha. 2021. Over Kapasitas Lapas, Pemerintah Dituding Melanggar HAM. https://www.cnnindonesia.com/nasional/20210912173723-12-693210/over-kapasitas-lapas-pemerintahdituding-melanggar-ham . Diakses 25 September 2021

3 Kanwil Sulawesi Selatan.2019. Restoratijuztice, Solusi Over Kapasitas Lapas Rutan. https:// sulsel.kemenkumham.go.id/pusat-informasi/artikel/4443-restorativejustice-solusi-over-kapasitas-lapasrutan. Diakses 25 September 2021.

4 Humas BNN.2019. Narapidana Narkotika Membeludak Dimana Letak Permasalahannya. https:// bnn.go.id/narapidana-narkotika-membeludak-dimana-letak-permasalahannya/. Diakses 25 September 2021.

5 Sistem Database Pemasyarakatan, Direktorat Jenderal Pemasyarakatan Kementerian Hukum dan HAM, diakses pada Rabu (9/9/2021) pukul 11.00 WIB. 
LAPAS KELAS II A PASIR PUTIH NUSAKAMBANGAN

LAPAS KELAS II A PEKALONGAN

LAPAS KELAS II A PERMISAN

NUSAKAMBANGAN

LAPAS KELAS II A PURWOKERTO

LAPAS KELAS II A SRAGEN

LAPAS KELAS II B BREBES

LAPAS KELAS II B CILACAP

LAPAS KELAS II B KLATEN

LAPAS KELAS II B PATI

LAPAS KELAS II B SLAWI

LAPAS KELAS II B TEGAL

LAPAS KHUSUS KELAS II A

KARANGANYAR

LAPAS NARKOTIKA KELAS II A

NUSAKAMBANGAN

LAPAS NARKOTIKA KELAS II B

PURWOKERTO

LAPAS PEMUDA KELAS II B PLANTUNGAN

LAPAS PEREMPUAN KELAS II A

SEMARANG

LAPAS TERBUKA KELAS II B KENDAL

LAPAS TERBUKA KELAS II B

NUSAKAMBANGAN

LEMBAGA PEMBINAAN KHUSUS ANAK

KELAS I KUTOARJO

RUTAN KELAS I SURAKARTA

RUTAN KELAS II A PEKALONGAN

RUTAN KELAS II B BANJARNEGARA

RUTAN KELAS II B BANYUMAS

RUTAN KELAS II B BATANG

RUTAN KELAS II B BLORA

RUTAN KELAS II B BOYOLALI

RUTAN KELAS II B DEMAK

RUTAN KELAS II B JEPARA

RUTAN KELAS II B KEBUMEN

RUTAN KELAS II B KUDUS

RUTAN KELAS II B PEMALANG

RUTAN KELAS II B PURBALINGGA

RUTAN KELAS II B PURWODADI

RUTAN KELAS II B PURWOREJO

RUTAN KELAS II B REMBANG

RUTAN KELAS II B SALATIGA

RUTAN KELAS II B TEMANGGUNG

RUTAN KELAS II B WONOGIRI

RUTAN KELAS II B WONOSOBO
91

257

502

676

538

270

488

298

339

334

274

306

448

73

22

299

13

14

60

632

203

108

120

287

137

189

204

332

147

149

225

159

239

202

97

136

132

352

157
124

800

221

488

400

161

254

144

197

224

150

696

250

250

34

174

160

50

65

298

197

71

152

217

94

156

100

108

113

104

120

92

120

122

112

56

94

250

73

\section{0}

0

127

39

35

68

92

107

72

49

83

0

79

0

0

72

0

0

0

112

3

52

0

32

46

21

104

207

30

43

87

73

99

66

0

143

40

41

115 
Selain itu data Ditjen Permasyarakatan menyabut kenaikan bandar narkotika mencapai 22, $13 \%$ sedangkan pengguna mencapai $11,46 \%$. Tingginya kenaikan ini tidak disertai dengan rehabilitasi, bahwasanya dalam impelementasinya rehabilitasi hanya biisa dilakukan untuk 1 dari 6 pengguna narkoba. ${ }^{6}$ Hal ini menjadi keprihatinan tersendiri bahwa pemenjaran pada dasarnya hanya memindahkan napi narkotika dari luar ke dalam penjara. Hal tersebut mengacu pada realita ketidakmampuan pemerintah dalam hal ini BNN untuk melakukan rehabilitasi terhadap banyaknya napi narkotika.

Mengenai hal tersebut pasal 127 undang-undang RI No.35 Tahun 2009 tentang Narkotika menentukan bahwa Ayat (1) Setiap Penyalah Guna:

a. Narkotika Golongan I bagi diri sendiri dipidana dengan pidana penjara paling lama 4 (empat) tahun;

b. Narkotika Golongan II bagi diri sendiri dipidana dengan pidana penjara paling lama 2 (dua) tahun; dan

c. Narkotika Golongan III bagi diri sendiri dipidana dengan pidana penjara paling lama 1 (satu) tahun.

Kemudian dalam ayat (2) "Dalam memutus perkara sebagaimana dimaksud pada ayat (1), hakim wajib memperhatikan ketentuan sebagaimana dimaksud dalam Pasal 54, Pasal 55, dan Pasal 103. (3) Dalam hal Penyalah Guna sebagaimana dimaksud pada ayat (1) dapat dibuktikan atau terbukti sebagai korban penyalahgunaan Narkotika, Penyalah Guna tersebut wajib menjalani rehabilitasi medis dan rehabilitasi sosial". Mengenai hal tersebut pasal 4 Undang-Undang narkotika turut menguatkan bahwa tujuan undang-undang ini untuk menjamin pengaturan upaya rehabilitasi medis dan sosial bagi Penyalah Guna dan pecandu Narkotika. Kemudian dipertegas kembali dalam Pasal 54 bahwa Pecandu Narkotika dan korban penyalahgunaan Narkotika wajib menjalani rehabilitasi medis dan rehabilitasi sosial.

Meskipun hukum positif Indonesia memberikan legitimasi yang kuat terkait kewajiban rehabilitasi namun realitas dalam praktik mengungkap bahwa tidak semua narapidana narkotika dapat menjalani rehabilitasi. Oleh karena itu penelitian ini perlu dilakukan untuk mengungkap lebih jauh mengenai perlunya pengguna narkoba yaitu penyalahguna dan pecandu narkoba untuk ditangani dengan upaya non penal dan

\footnotetext{
6 Humas Balitbangkumham. 2019. Hanya Sedikit Napi Narkotika Yang Terima Rehabilitasi. https:// www.balitbangham.go.id/detailpost/hanya-sedikit-napi-narkotika-yang-terima-rehabilitasi. Diakses 25 September 2021
} 


\section{TURNASN: 2723-0147}

dekriminalisasi penyalahguna narkoba guna mengurangi tingkat overcapacity lembaga permasyarakatan di Indonesia

\section{IDENTIFIKASI MASALAH}

Penulis akan memberikan batasan permasalahan yang akan dibahas dalam penelitian ini, yaitu:

1. Bagaimanakah penanganan pengguna narkoba, pecandu dan penyalahguna narkoba?

2. Bagaimanakah cara mengurangi tingkat overcapacity bagi penyalahguna narkoba di lembaga permasyarakatan Indonesia?

\section{METODE}

Metode penelitian yang digunakan dalam penelitian ini berupa metode penelitian normatif. dengan pengumpulan data melalui kepustakaan, focusing on reading and analysis of the primary and secondary materials sebagaimana yang diungkapkan Soerjono Soekanto ${ }^{7}$. Adapun sumber penelitian dari bahan primer dan sekunder, untuk bahan primer diperoleh dari peraturan perundang-undangan dalam hal ini khususnya Undang-undang Nomor 35 Tahun 2009 tentang Narkotika. Kemudian untuk bahan sekunder penulis menggunakan buku hukum, jurnal hukum dan berita-berita tertentu untuk memperoleh data guna menunjang penelitian ini.

\section{IV.HASIL DAN PEMBAHASAN}

\section{A. Pengguna narkoba dalam hal ini pecandu dan penyalahguna perlu ditangani dengan upaya non penal}

Arah kebijakan hukum pidana atau politik criminal merupakan upaya rasional masyarakat untuk menanggulangi kejahatan. Dalam hal ini prof. Sudarto mengemukakan bahwa politkk criminal dalam arti sempit adalah keseluruhan asas dan metode yang menjadi dasar dari reaksi terhadap pelanggaran hukum berupa pidana. Dalam arti luas politik criminal berarti keseluruhan fungsi dari aparatur penegak hukum, termasuk didalamnya pengadilan hingga polisi. Kemudian dalam arti yang paling luas ialah

\footnotetext{
7 Soekanto, Soerjono \& Sri Mamudji, Penelitian Hukum Normatif (Suatu Tinjauan Singkat), Jakarta: PT Raja Grafindo Persada, 2006, hlm. 23-24.
} 
keseluruhan kebijakan yang dilakukan melalui peraturan perundang-undangan dan badanbadan resmi yang bertujuan menegakkan norma sentral dari masyarakat ${ }^{8}$.

Maraknya kasus narkotika yang selalu naik setiap tahun membuktikan bahwa upaya penal tidak memberikan hasil yang memuaskan sehingga membutuhkan pendekatan kebijakan integral yang tidak hanya melibatkan aparat penegak hukum tapi juga intansi lainnya yang memperhatikan sebab dan kondisi korban. Terkait hal ini perlu kesadaran bersama bahwa kejahatan yang ada bukan semata-mata dipandang sebagai masalah hukum namun juga dipandang sebagai masalah sosial. Sehingga kejahatan itu sendiri bukan semata-mata tugas dari aparat penegak hukum baik itu kepolisian, kejaksaan, maupun pengadilan namun juga tugas dari masyarakat sebagai bagian intergral dari pendekatan kebijakan. Oleh karena itu penting untuk menangani kasus narkotika dengan berfokus pada upaya preventif dengan menanggulangi sebab dan kondisi dari korban. Dalam hal ini penyalahguna dan pecandu narkoba dipandang sebagai korban, yang karenanya harus memperoleh rehabilitasi untuk mengembalikan dirinya menjadi manusia yang sehat

Upaya penal dalam hal ini pemenjaraan bagi penyalahguna dan pecandu narkoba tidak menjamin keberhasilan rehabilitasi bagi mereka. Hal tersebut dibuktikan dengan banyaknya kasus penyalahgunaan narkotika yang meninggal yaitu hampir 50 orang meninggal setiap harinya ${ }^{9}$. Selain itu tidak semua daerah memiliki panti rehabilitasi, sehingga hal ini juga menjadi hambatan dalam rehabilitasi napi narkotika adapun panti rehabilitasi milik swasta diperkirakan membutuhkan biaya yang jauh lebih mahal ${ }^{10}$.

Dengan upaya non penal, kasus pecandu dan penyalahguna narkoba akan diprioritaskan dengan penanganan rehabilitasi. Sehingga upaya ini akan mendorong kesembuhan narapidana narkotika dibanding dengan upaya penal yang berfokus pada pemenjaraan. Dalam hal ini pasal 1 ayat (13) undang undang Nomor 35 tahun 2009 tentang narkotika menyebut bahwa Pecandu Narkotika adalah orang yang menggunakan atau menyalahgunakan Narkotika dan dalam keadaan ketergantungan pada Narkotika, baik secara fisik maupun psikis. Ayat (15) menyebut bahwa Penyalah Guna adalah orang yang

\footnotetext{
8 Arief, Barda Nawawi. 2010. Bunga Rampai Kebijakan Hukum Pidana, Perkembangan Penyusunan Konsep KUHP Baru, hlm. 3.

9 Kominfo 2015. BNN Ingatkan 50 Orang Meninggal Setiap Hari Karena Narkoba. https:// kominfo.go.id/content/detail/4883/bnn-ingatkan-50-orang-meninggal-setiap-harikarenanarkoba/0/sorotan media. Diakses 26 September 2021

${ }^{10}$ Deden Gunawan. 2021. Tiga Alasan Pengguna Narkoba Banyak Dijebloskan Ke Penjara. https:// news.detik.com/berita/d-5726803/tiga-alasan-pengguna-narkoba-banyak-dijebloskan-ke-penjara . Diakses 26 September 2021
} 
menggunakan Narkotika tanpa hak atau melawan hukum. Kemudian penjelasan Pasal 54 Yang dimaksud dengan "korban penyalahgunaan Narkotika" adalah seseorang yang tidak sengaja menggunakan Narkotika karena dibujuk, diperdaya, ditipu, dipaksa, dan/atau diancam untuk menggunakan Narkotika.

Penggunaan narkotika akan menyebabkan ketergantungan yang menyebabkan seseorang kesulitan untuk lepas dari pengaruh narkotika bahkan jika tidak ditangani dengan upaya medis yang tepat ketergantungan dapat menyebabkan kematian. Demikian undang-undang narkotika dalam pasal 1 ayat (14) menyebut bahwa Ketergantungan Narkotika adalah kondisi yang ditandai oleh dorongan untuk menggunakan Narkotika secara terusmenerus dengan takaran yang meningkat agar menghasilkan efek yang sama dan apabila penggunaannya dikurangi dan/atau dihentikan secara tiba-tiba, menimbulkan gejala fisik dan psikis yang khas.

Demikian pada dasarnya hukum positif mengatur mengenai rehabilitasi yang wajib dijalani biak oleh pecandu maupun penyalahguana narkotika, namun undang-undang ini bertentangan dengan peraturan lain yang mengatakan bahwa pada dasarnya rehabilitasi diatur sebagai hak bukan sebagai kewajiban. Hal tersebut didasarkan pada pasal 3 ayat (1) BAB III Pelaksanaan Peraturan Bersama (7) Lembaga Negara tentang penanganan Pecandu Narkotika dan Korban Penyalahgunaan Narkotika ke Dalam Lembaga Rehabilitasi. Meskipun dalam asas hukum pidana yang berbunyi Lex Specialis Derogat Lex Generalis, bahwa asas ini memang cukup menjelaskan bahwa tentu undang-undang narkotika sebagai peraturan khusus memiliki kedudukan lebih tinggi dan mengesampingkan Peraturan Bersama tersebut. Namun melihat realitas yang terjadi mengenai masih minimnya rehabiilitasi, dan lembaga pelaksana rehabilitasi cukup membuktikan bahwa dengan adanya peraturan tersebut dan didukung oleh adanya keadaan yang demikian menyatakan bahwa rehabilitasi masih belum menjadi kebijakan yang diprioritaskan.

Riset menunjukkan bahwa mengkombinasikan pendekatan hukum dengan penanganan medis-psokologis untuk perilaku adiktif dapat berakibat efektif terhadap menurunnya penyalahgunaan narkoba dan angka kejahatan. Individu pengguna narkoba yang dipaksa secara legal untuk menjalani treatment cenderung mengikuti proses penyembuhan untuk rentang waktu yang lama dan lebih positif hasilnya. Peran instansi hukum juga mempengaruhi efektivitas treatment, contohnya prakarsa semacam ini di 
Amerika Serikat, yang ditangani langsung oleh US Departement of Justice Drug Courts Program Office, dengan alternatif pemenjaraan melalui program Treatment Accountability and Safer Communities ${ }^{11}$.

\section{B. Dekriminalisasi penyalahguna narkoba dapat mengurangi tingkat overcapacity lembaga permasyarakatan di Indonesia}

Dekriminalisasi dan depenalisasi pengguna narkotika sudah lama dibicarakan bahkan sudah diwacanakan di tahun 2014 namun hinga kini belum dapat dilaksanakan. Dalam hal ini dekriminalisasi bukan berarti mengeluarkan kejahatan narkotika dari ruang lingkup hukum pidana, Perbuatan tersebut tetap diancam dengan hukuman pidana namun sanksi yang dijatuhkan bukan lagi penjara tapi rehabilitasi. Ini merupakan bentuk usaha memprioritaskan rehabilitasi bagi pengguna dan penyalahgunanarkoba sebagai upaya pemulihan, bukan lagi memprioritaskan penjara terhadap setiap kejahatan narkotika, hanya saja penyalahguna dan pecandu adalah korban yang semestinya direhabilitasi.

Konsep demikian didorong dengan sebuah konsep yang diperkenalkan oleh Europion Monitoring Centre for Drugs and Drug Addiction (EMCDDA) yang berpusat di Lisbon, tahun 2005, yaitu Decriminalisation comprises removal of a conduct or activity from the sphere of law. Prohibition remains the rule, but sanctions for use (and its preparatory acts) no longer fal within the framework of the criminal law.

Pada dasarnya konsep demikian didukung dengan insrumen hukum positif indonesia, bahwa terdapat kewenangan bagi hakim untuk menjatuhkan pidana penjara atau rehabilitasi. Berdasarkan UU Narkotika No. 35/2009 pasal 128 terdapat pelunakan dari hukum pidana bahwa bagi mereka yang melapor secara sukarela maka dia tidak dipidana meskipun perbuatannya termasuk melanggar hukum ${ }^{12}$.

Prof. Barda Nawawi Arif menggolongkan Perlindungan korban dalam 2 makna;

a. Perlindungan hukum untuk tidak menjadi korban tindak pidana (perlindungan HAM atau kepentingan hukum seseorang)

b. Perlindungan untuk memperoleh jaminan atau santunan hukum atas penderitaan atau kerugian orang yg telah menjadi korban tindak pidana. Bentuk santunan dapat berupa pemulihan nama baik/rehabilitasi, pemulihan

\footnotetext{
${ }^{11}$ Reza Indragiri Amriel. Psikologi Kaum Muda Pengguna Narkoba. Salemba Humanika, Jakarta, 2008, hlm. 76.

${ }^{12}$ Humas BNN.2015. Dekriminalisasi Pengguna Narkoba Tidak Sama Dengan Legalisasi, https://bnn.go .id/dekriminalisasi-pengguna-narkoba-tidak-sama-dengan-legalisasi/. Diakses 26 September 2021
} 
keseimbangan batin antara lain dengan permaafan, pemberian ganti rugi (restitusi, kompensasi, jaminan atau santunan kesejahteraan sosial). Hak korban akan ganti rugi pada dasarnya merupakan bagian integral dari HAM di bidang kesejahteraan atau jaminan sosial seperti terdapat dalam artikel 25 $\mathrm{UDHR}^{13}$.

Berdasarkan hal tersebut penulis menganalisa bahwasanya narapidana narkotika dalam hal ini pecandu dan penyalahguna semestinya dipandang sebagai korban yang berhak untuk memperoleh perlindungan hukum untuk tidak menjadi korban tindak pidana hal demikian menyangkut pula kepentingan hukum seseorang yang wajib dilindungi negara dan Hak asasi dari pecandu maupun penyalahguna untuk sembuh dari ketergantungan narkotika. Selain itu mereka berhak atas jaminan atau rehabilitasi atas kerugian yang diperoleh sebagai korban dalam hal ini rehabilitasi medis dan rehabilitasi sosial.

Oleh karena itu dipandang perlu untuk mengupayakan dekriminalisasi pengguna narkotika mengingat keduanya merupakan korban dari tindak pidana pengedaran narkotika. Pembaharuan hukum pidana perlu dilakuakn mengingat pula dampat terhadap korban dan biaya yang ditanggung negara antara kriminalisasi yang jauh lebih banyaj memerlukan biaya tinggi dibanding dekriminalisasi. Hal ini didukung pendapat dari M.Cherif Bassiouni bahwa ada beberapa hal yang seharusnya diperhatikan dalam melakukan kriminalisasi dan dekriminalisasi ${ }^{14}$ :

1. Keseimbangan sarana yang digunakan dalam hubungannya dengan hasil yang ingin dicapai:

2. Analisis biaya terhadap hasil yang diperoleh dalam hubungannya dengan tujuan yng dicari

3. Penilaian atau penaksiran tujuan-tujuan yang dicari dala kkaitanyya dengan peioritas lainnya dalam alokasi sumber daya manusia:

4. pengaruh sosial dari kriminalisasi dan dekriminalisasi

\footnotetext{
${ }^{13}$ Arief, Barda Nawawi, Masalah Penegakan Hukum dan Kebijakan Hukum Pidana dalam Penanggulangan Kejahatan, Kencana Prenada Media Group, Jakarta: 2010, hlm. 61-61.

${ }^{14}$ M. cheris Bassiouni, Substantive Criminal Law, 1978, hlm. 82., dikutip dalam buku Bunga Rampai Kebijakan Hukum Pidana oleh Prof Barda Nawawi Arief, hlm. 33.
} 


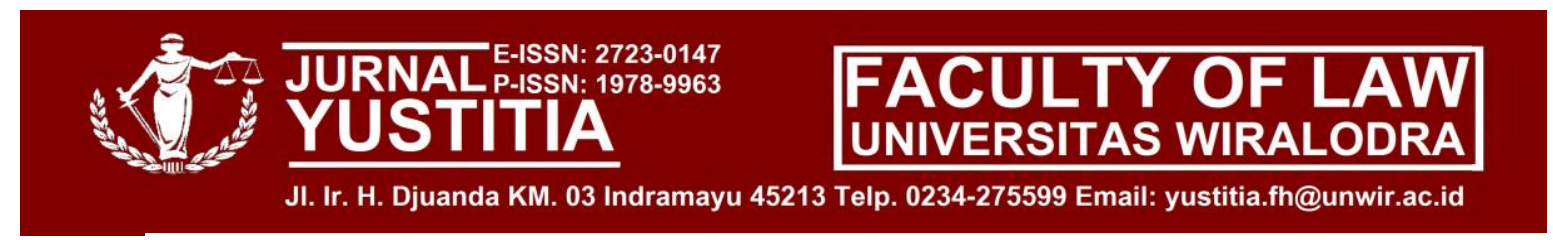

Diperkuat dalam Simposium Pembaruan Hukum Pidana Nasional pada Bulan Agustus 1980 di Semarang, bahwa terdapat beberapa kriteria untuk melakukan kriminalisasi dan dekriminalisasi diantaranya sebagai berikut ${ }^{15}$ :

1. Apakah perbuatan itu tidak disukai atau dibenci oleh masyarakat karena merugikan, atau dapat merugikan, mendatangkan korban atau dapat mendatangkan korban.

2. apakah biaya mengkriminalisasi seimbang dengan hasilnya yang akan dicapai.

3. apakah akan semakin menambah beban aparat penegak hukum yang tidak dapat diemban.

4. apakah perbuatan tersebut menghambat atau menghalangi cita-cita bangsa sehingga tindakan tersebut mengancam keselamatan bangsa.

Terkait hal tersebut pengedaran narkoba tentu merugikan banyak pihak yang tidak hanya menimbulkan korban namun juga kerugian materil dan immaterial. Korban berupa masyarakat luas yang terpengaruh dan terancam dengan keberadaan narkotika yang disalahgunakan sehingga juga berdampak pada timbulnya pihak-pihak yang disebut dengan pecandu juga penyalahguna. Kemudian terkait biaya kriminalisasi tentu tidak seimbang dengan hasil yang hendak dicapai. Kriminalisasi bertujuan untuk memberikan ketertiban dalam masyarakat, menimbulkan efek jera pada pelaku dan menimbulkan rasa takut bagi siapa yang akan atau berniat mencoba tindak pidana tersebut. Namun adanya kriminalisasi tidak didukung dengan kapasitas lembaga permasyarakatan yang memadai, Sumber daya manusia, dan biaya pembinaan narapidana termasuk alternatif untuk beberapa narapidana narkotika yang melakukan rehabilitasi. Biaya ini tidak seimbang sebab aparat selain menanggung biaya hidup atau pembinaan narapidana masih menanggung biaya rehabilitasi terlebih hanya 1 dari 6 narapidana narkotika yang direhablitasi. Hal demikian menyimpang dari tujuan pemidanaan yang hendak memperbaiki pelaku untuk siap dikembalkan dalam lingkungan masyarakat. Oleh karena itu dekriminalisasi dari segi biaya juga menjadi pertimbangan yang tepat bahwa prioritas dalam rehabilitasi tentu akan lebih menjangkau jaminan bagi narapidana narkotika untuk dipulihkan dan peniadaan pidana penjara untuk penyalahguna dan pecandu akan menghemat biaya juga sumber daya manusia dari negara.

\footnotetext{
${ }^{15}$ Simposium Pembaharuan Hukum Pidana Nasional pada Agustus 1980 di Semarang sebagaimana dikutip dalam buku Bunga Rampai Kebijakan Hukum Pidana oleh Prof Barda Nawawi Arief, hlm. 32.
} 


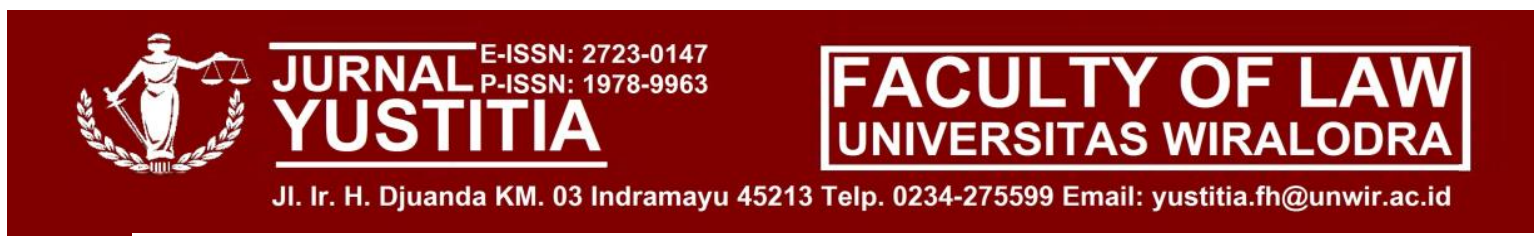

Kemudian untuk poin 3 terkait beban yang ditanggung aparat penegak hukum bahwasanya kriminalisasi memberikan beban 2 kali lipat untuk pembinaan sekaligus koordinasi rehabilitasi untuk narapidana narkotika. Selain itu dari sisi kriminalisasi tindak pidana terkait narkotika memang dilakukan demi melindungi keselamatan masa depab bangsa. Akan tetapi kriminalisasi lebih tepat dijatuhkan pada pengedar dan tidak pada pecandu maupun penyalahguna sebab mereka tetaplah pihak-pihak yang harus disembuhkan dan diselamatkan.

Oleh karena pertimbangan tersebut diperlukan penempatan pecandu dan penyalahguna narkotika sebagai korban sehingga beban lapas terkait banyaknya narapidana narkotika yang mencapai $50 \%$ dari total narapidana dapat ditanggulangi dengan adanya dekriminalisasi pengguna narkoba yang berfokus bahwa pengguna tetap tindak pidana tetapi sanksi yang dijatuhkan bukan pemenjaraan namun rehabilitasi.

\section{PENUTUP}

\section{A. Simpulan}

1. Politik kriminal sebagai upaya rasional masyarakat berupa kebijakan yang dituangkan dalam peraturan perundang-undangan maupaun badan resmi guna menegakkan norma dalam masyarakat. Politik criminal dalam kejahatan narkotika perlu dilakukan karena meskipun undang-undang menentukan bagi pecandu dan penyalahguna narkotika wajib rehabilitasi namun nyatanya peraturan ini berbenturan dengan Pelaksanaan Peraturan Bersama (7) Lembaga Negara tentang penanganan Pecandu Narkotika dan Korban Penyalahgunaan Narkotika ke Dalam Lembaga Rehabilitasi.

2. Dalam pelaksanaan peraturan bersama tersebut menyatakan rehabilitasi sebagai hak bukan kewajiban hal ini didukung dari fakta lapangan bahwa hanya 1 dari 6 narapidana narkotika yang memperoleh rehabilitasi. Oleh karena itu upaya non penal diperlukan guna memprioritaskan rehabilitasi sebagai upaya pemulihan korban. Selain itu overkapasitas lapas sebagai permasalahan krusial saat ini perlu dipandang bukan saja sebagai permasalahan hukum tapi juga permasalahan sosial. Dekriminalisasi sebagai penyelesaian overkapasitas lapas perlu diupayakan sebagai langkah pembaharuan hukum pidana selain itu mempertimbangkan terkait efektivitas biaya dan beban aparat penegak hukum. 


\section{B. Saran}

Perlunya pemahaman yang paripurna bagi para aparat penegak hukum, dalam hal penegakan hukum terhadap para pecandu dan pengguna narkotika, selain itu para ahli hukum juga perlu melakukan suatu kajian mendalam guna melakukan penyatuan pandangan terhadap arah pemidanaan terhadap para pecandu dan pengguna narkotika di Indonesia. Segala bentuk kejahatan tidaklah selalu harus diupayakan tindakan penjara, mengingat kondisi Lapas yang semakin kronis, disamping itu banyak kejahatan yang bisa untuk dilakukan upaya mediasi, sehingga dengan hal itu kita dapat mengimplementasikan mazhab Restorative Justice. Selain itu masyarakat sebagai control social harus mulai membuang pemikiran punitif.

\section{DAFTAR PUSTAKA}

\section{A. Buku :}

Arief, Barda Nawawi. 2010. Bunga Rampai Kebijakan Hukum Pidana, Perkembangan Penyusunan Konsep KUHP Baru, Jakarta: Kencana Prenada Media Group

Arief, Barda Nawawi. 2010. Masalah Penegakan Hukum dan Kebijakan Hukum Pidana dalam Penanggulangan Kejahatan, Jakarta: Kencana Prenada Media Group. $7-261$

M. Cheris Bassiouni, Substantive Criminal Law, 1978,

Reza Indragiri Amriel. 2008. Psikologi Kaum Muda Pengguna Narkoba. Salemba Humanika. Jakarta.

Sajipto Rahardjo, Ilmu Hukum, Bandung: PT Citra Aditya Bakti, 2014

Soerjono Soekanto \& Sri Mamudji, Penelitian Hukum Normatif (Suatu Tinjauan Singkat). Jakarta: PT Raja Grafindo Persada, 2006)

\section{B. Jurnal}

Angrayni, Lysa. 2018. Efektivitas Rehabilitasi Pecandu Narkotika (Studi di Loka Rehabilitasi Badan Narkotika Nasional Batam), Jurnal Hukum Respublica. Vol.18.No.1, hlm.78-96. 
Dewan, Parasian Simanungkalit. 2012. Model Pemidanaan Yang Ideal Bagi Korban

Pengguna Narkoba Di Indonesia. Jurnal Yustitia. Vol. 1.No. 3, hlm. 80-93.

Fitri, Silvia. 2020. Implementasi Kebijakan Rehabilitasi Pengguna Narkoba pada

Badan Narkorika Nasional Provinsi Sumatera Barat. Jurnal of Civic Education. Vol. 3. No. 3, hlm. 231- 242.

Hartanto, Wenda. 2017. Penegakan Hukum Terhadap Kejahatan Narkotika dan Obat-

Obat Terlarang Dalam Era Perdagangan Bebas Internasional Yang Berdampak Pada Keamanan dan Kedaulatan Negara. Jurnal Legislasi Indonesia. Vol.14.No.1, hlm.1-16.

Purnamasari, Andi Intan.2019. Dekriminalisasi Tindak Pidana: Membedah Keadilan Bagi Terpidana Dan Mantan Terpidana.Vol.2 No.1, hlm. 13-23.

Subantara, I Made, A.A. Sagung Laksmi Dewi, \& Luh Putu Suryani. 2020. Rehabilitasi Terhadap Korban Penyalahgunaan Narkotika Di Badan Narkotika Nasional Provinsi Bali. Jurnal Preferensi Hukum. Vol.1 No.1, hlm. 243-248.

\section{Sumber Lain}

Asprilla Dwi Adha. 2021. Over Kapasitas Lapas, Pemerintah Dituding Melanggar HAM. $\quad$ https://www.cnnindonesia.com/nasional/20210912173723-12693210/over-kapasitas-lapas-pemerintah-dituding-melanggar-ham. Diakses 25 September 2021

Deden Gunawan. 2021. Tiga Alasan Pengguna Narkoba Banyak Dijebloskan Ke Penjara. $\quad$ https://news.detik.com/berita/d-5726803/tiga-alasan-penggunanarkoba-banyak-dijebloskan-ke-penjara. Diakses 26 September 2021

Humas Balitbangkumham. 2019. Hanya Sedikit Napi Narkotika Yang Terima Rehabilitasi. https://www.balitbangham.go.id/detailpost/hanya-sedikit-napinarkotika-yang-terima-rehabilitasi. Diakses 25 September 2021

Humas BNN.2015. Dekriminalisasi Pengguna Narkoba Tidak Sama Dengan Legalisasi. https://bnn.go.id/dekriminalisasi-pengguna-narkoba-tidak-samadengan-legalisasi/. Diakses 26 September 2021

Humas BNN.2019. Narapidana Narkotika Membeludak Dimana Letak Permasalahannya. https://bnn.go.id/narapidana-narkotika-membeludakdimana-letak-permasalahannya/ . Diakses 25 September 2021. 


\section{IUPNAL-ISSN: 2723-0147

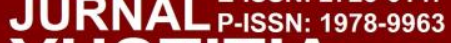 \\ YUSTITIA

JI. Ir. H. Djuanda KM. 03 Indramayu 45213 Telp. 0234-275599 Email: yustitia.fh@unwir.ac.id

Kanwil Sulawesi Selatan. 2019. Restoratijuztice, Solusi Over Kapasitas Lapas Rutan. https://sulsel.kemenkumham.go.id/pusat-informasi/artikel/4443restorativejustice-solusi-over-kapasitas-lapas-rutan. Diakses 25 September 2021.

Kominfo 2015. BNN Ingatkan 50 Orang Meninggal Setiap Hari Karena Narkoba. https://kominfo.go.id/content/detail/4883/bnn-ingatkan-50-orang-meninggal -setiap-hari-karenanarkoba/0/sorotan_media. Diakses 26 September 2021 